\title{
Blood DNA
}

National Cancer Institute

\section{Source}

National Cancer Institute. Blood DNA. NCI Thesaurus. Code C158416.

DNA extracted from nucleated cell from the peripheral blood. 